\title{
MACROECONOMIC EFFECTS OF BUDGET DEFICIT IN NIGERIA
}

\author{
Akamobi Obiageli Gloria ${ }^{1}$, \\ Unachukwu Ijeoma Blessing ${ }^{2 i}$ \\ ${ }^{1}$ Department of Economics, \\ Chukwuemeka Odumegwu Ojukwu University (COOU), \\ Anambra State, \\ Nigeria \\ ${ }^{2}$ Department of Economics Education, \\ School of Languages, \\ College of Education (Technical), \\ Umunze, Anambra State, \\ Nigeria
}

\begin{abstract}
:
This study probed the macroeconomic effects of budget deficit in Nigeria. Specifically, it seeks to probe the effect of budget deficit on private investment and public investment in Nigeria by adopting the ADF unit root test and ARDL model, Granger Causality test and the short-run diagnostics and stability using annual time series data covering 37 years from 1981 to 2019. The variables employed include - Growth rate of real gross domestic product, private investment (Gross Fixed Capital Formation) as a percentage of GDP, public investment measured as ratio government capital expenditure to GDP, budget deficit, money supply measured as ratio of GDP, inflation rate measured by annual year-on-year inflation rate, interest rate, labour force participation rate. The research findings admitted that, budget deficit have positive and significant impact on economic growth in Nigeria. Therefore, government budget deficit has no crowding out effect on investment. The study also reveals that budget deficit has negative and insignificant impact on private investment in Nigeria. In addition, further investigation shows budget deficit have positive and significant impact on public investment in Nigeria. Also, the study asserts that there is unidirectional causality running from budget deficit to economic growth, private investment and public investment. Based on the research findings of this study, Government must ensure and maintain strong fiscal discipline without compromising the wellbeing of the citizenry by allocating budget spending to sectors that can translate the deficit into high economic growth both in the short and long runs. Furthermore, budget deficit financing in Nigeria should be focused on the productive sectors of the economy. This is because deficit financing has merely
\end{abstract}

iCorrespondence: email go.akamobi@coou.edu.ng, ijeoma.unachukwu@fcetumunze.edu.ng 
resulted in economic instability indicating that sound policies are needed to achieve economic stability in Nigeria.

JEL: E02, H61, E22

Keywords: budget deficit, private investment, public investment, economic growth

\section{Introduction}

The relationships between government budget deficits and macroeconomic performance have received tremendous attention amongst researchers and policy makers around the globe. Persistent increases in budget deficits have assumed greater height in many emerging economies like Nigeria (Oladipo \& Akingbola, 2011). However, the development of deficit financing is often traced to adoption of the Keynesian inspired public expenditure which Nigeria adopted to motivate economic performance. Keynes recommended deficit spending to moderate or end a recession. To him, when an economy is recording high unemployment, an increase in government purchases will help a market for business output thereby creating income which through multiplier effect encourages the demand for business output. The policy of deficit spending has however posed challenges to the Nigeria economy with regard to its effectiveness and the accumulation of debt, the justification of growth notwithstanding (Anyanwu \& Oaikhenan, 1995; Ogboru, 2006).

Persistent deficits were perceived to have adverse effects on the macroeconomic indicators. Various governments having the power to exercise a lot of influence over economic activities and budget deficit being their prominent instrument felt that the deficits have to continue to stimulate the economy. In 1986, the government introduced SAP with the hope that with restructuring of the economy, there would be reduction in the deficit spending. But this appears not to have been achieved as the deficits continue to escalate on yearly basis. The consequences of such deficit spending on many macroeconomic variables cannot be underestimated (Oladipo \& Akinbobola, 2011).

However, the effect of budget deficit on private investment and economic growth is a controversial issue among Economists. Some argues that it would crowd-in investments while others think it will have crowding-out effects. The critics of budget deficit argue that it will push up interest rates which will consequently crowd-out private investments from productive sectors as many investors will prefer to investment in government bonds at higher interest since it is safer (Checherita \& Rother, 2010; Calderon \& Fuentes, 2013; Irons \& Bivens, 2010).

The effect of budget deficit on public investment changes with time. In the shortrun, budget deficit is expected to boost public investment in infrastructures (IMF, 2015), but in the long-run as the debt pile up the interest payments will eat up substantial share of the government expenditure, leaving less money for public investment in infrastructure and education which will eventually hinder economic growth (Alesina, et al., 2018). The Keynesian economists argue that government should run a large budget 
deficit in order to stimulate the economy in the short-run especially during recession. However, this short-term perspective has been contended by some economists arguing that the government cannot boost the economy effectively by increasing its spending substantially in such a manner without taking into account some important considerations (Bedard, 2016). The impact of budget deficit through government debts on economic growth depends on how the debt fund is being expended. If the fund is used to finance capital and developmental projects such as transport system, power projects, water supply, human capital development (in terms of quality education, sound health care etc), the productive capacity of the country will be improved and will consequently lead to economic growth especially if the country has a high growth potentials (Nimani, 2013). Besides, the returns that would be generated from these infrastructures could be used to service and perhaps, repay the debt. On the other hand, if the public debt is used for recurrent expenditures such as administrative costs, the government would be forced to raise tax rate in the future in order to service the debt. This will not only scare away investors and hinder economic growth, servicing the debt will become a major burden to future generations (Alesina, et al., 2018).

Be that as it may, lack of fiscal discipline poses a threat to macroeconomic stability in Nigeria. Thus, large budget deficits overtime is mostly explained as a consequence of corruption ranging from planned political decision order than the resultant external shock or reactions on prevailing internal economic situation as stipulated by Sheneko (1993); Olomola (2000) and Obadan (2003). In view of the above, the understanding of the effect of budget deficit on economic growth of Nigeria becomes paramount.

\subsection{Statement of the Problem}

The rapid development of an economy requires industrialization and for a country to be industrialized there must be reasonable level of investment to boast production. That is why the industrialized nations appear to be most developed in the world. However, to tap from the benefit inherent in economic growth, there must be increase in level of investment and the production. Therefore, for a country to promote production activities there is the needs for a substantial injection of capital which may be probably earn through taxations and borrowings. It is on this ground that Keynesian perceived government borrowing reasonable and argues that it does not have any harm on economic performance of Nigeria.

The aim of government borrowing as one of the instruments of deficit financing is channel towards achieving growth and development. Overtime, this borrowing has always been in excess compared to the generated revenue. The consistent increase in government budget deficits in recent time has rekindled debates about the effects of budget deficit on economic performance. While the effects of budget deficit on the economy can operate through a number of different channels such as exchange rate, interest rate, national savings and gross capital formation among others, many of the recent concerns about government borrowing have focused on the potential interest rate effect which trickle dawn to other macroeconomic indicators. Higher interest rates caused by expanding government debt may reduce investment, inhibit interest-sensitive durable 
consumption expenditure, and decrease the value of assets held by households, thus indirectly dampening consumption expenditure through a wealth effect (Glenn, 2012).

In addition, rise in government borrowing may cause problem of rise in bond yields and inflation if governments fund deficits by printing money. If the government sells more bonds, it is likely to cause interest rates to increase. This is because the authority may need to increase interest rates in order to attract investors to buy the extra debt. Therefore, increased government borrowing may cause a decrease in the size of the private sector which may crowd out investment. Also, the likelihood of higher taxes and spending cuts may reduce the incentives to work. In extreme circumstances government may increase the money supply to pay the debt. But if government decides to sell short term gilts to the banking sector then there will be an increase in the money supply. This is because banks see gilts as near money, therefore they can maintain their lending to customers. Thus, rapid rise in government borrowing may lead to not just a rise in real debt but a rise in debt to GDP. This means debt burdens are a bigger percentage of aggregate output.

In view of the above, the ever rising budget deficit has attracted the attention of economists and policy makers and brings the need for formulation and implementation of macroeconomic policies with the hope of improving the management of the economy. Such policies are expected to address fiscal deficit management particularly the size and financing patterns of government deficits, the structure of taxation and the level of the composition of public expenditure. Some of the policies of Nigerian government in her effort to reduce the high budget deficits include the establishment of the Fiscal Responsibility Commission in 2007 which was meant to help to raise the level of fiscal prudence. The commission was backed by an Act in 2007 which expected the Federal Government not to exceed the threshold of 3\% of GDP in its budget deficit. Another one is the Medium Term Expenditure Framework (MTEF) and Fiscal Strategy Paper (FSP) of 2012 - 2015. Their aim according to MTEFFSP (2012-2015) is to help in reducing government spending from the height reached in previous years as a result of majorly fiscal stimulus extended during the peak of global economic crisis. When the deficit is reduced, opportunity for greater private sector participation and the growth of the economy will be enhanced. In the 2013 budget termed "Fiscal Consolidation with Inclusive Growth" the present Nigeria government mapped out supportive fiscal measures to reduce deficit and encourage private sector investment just to step up the economic activities and to promotes its performance.

In spite of the above measures fiscal deficit has become a recurring decimal in Nigeria. Large fiscal deficit may have a lot of consequences on the country's economic growth. For instance, Ikpama (2010) has argued that a higher fiscal deficit may lead to increased government borrowing and high debt servicing which may force the government to cut back in spending on relevant sectors of the economy such as health, education, infrastructure, human and physical capital development. He claims that it also causes exchange rate fluctuation and the crowding out of private investment as discussed earlier. For instance, Ezeabasili, et al. (2012) have noted that the major causes of inflation in Nigeria are the widening fiscal imbalances and the sources of deficit financing. 
According to them, a feature of the Nigerian economy has become a transition to high rates of inflation. They note that in the 1970s the overall inflation averaged $15.3 \%$, while in the 1980s it increased to an average of $22.9 \%$ and in the 1990 s the average inflation rate soared to $30.6 \%$. They claim that the transition to high inflation rate over these periods must have resulted in substantial real cost and big losses in income and a low performance of the economy as a whole as a result of the widening fiscal deficits. However, Ranjan (2013) is of the view that if productive public investments increase and if public and private investments are complementary the negative impact of high borrowings on economic growth may be offset. Therefore, on this note, it is pertinent to investigate further the influence of government budget deficit on economic growth of Nigeria.

\subsection{Research Objectives}

Given the above discussed, the following research objectives are therefore formulated to guide the study.

1) To explore the impact of budget deficit on growth of GDP of Nigeria;

2) To evaluate the effect of budget deficit on private investment of Nigeria;

3) To determine the effect of budget deficit on public investment of Nigeria.

\section{Review of Literature}

\subsection{Conceptual Framework}

A government budget is a government document presenting the government's proposed revenues and spending for a financial year. The government budget balance, also alternatively referred to as general government balance, public budget balance, or public fiscal balance, is the overall difference between government revenues and spending. A positive balance is called a government budget surplus, and a negative balance is a government budget deficit. A budget is prepared for each level of government (national to local) and takes into account public and social obligations. The government budget balance is further differentiated by closely related terms such as primary balance and structural balance (also known as cyclically-adjusted balance) of the general government. The primary budget balance equals the government budget balance before interest payments. The structural budget balances attempts to adjust for the impacts of the real GDP changes in the national economy. The meaning of "deficit" differs from that of "debt", which is an accumulation of yearly deficits. Deficits occur when a government's expenditures exceed the revenue that it generates. The deficit can be measured with or without the interest payments on the debt. The primary deficit is defined as the difference between current government spending on goods and services and total current revenue from all types of taxes net of transfer payments. Epaphra (2017) defined budget deficit as the extent to which government expenditure exceeds government revenue which needs to be financed. Nwanna and Umeh (2019) defined fiscal deficit as a situation where current expenditure exceeds current expected income 
However, economic growth is a commonly used macro-economic indicator that is popular among Economists. It is used to measure the productive capacity of a country and often expressed in relation to the Gross Domestic Product (GDP). However, it has been defined in different ways. In the view of Schumpeter (1934), economic growth is a slow and steady change in the economy over a long term stimulated by gradual increase in the rate of savings and population. The view of Schumpeter on economic growth was accepted and elaborated by many other economists such as: Kindle Berger (1965), Friedmann (1972) and so on. Kindle Berger (1965) defined economic growth as a situation where there is more output in an economy.

\subsection{Theoretical Literature}

\section{The Ricardian View of Budget Deficits}

In the Ricardian perspective, a deficit financed cut in current taxes for a given path of government spending leads to higher future taxes that have the same present value as the initial cut. Hence holding fixed the path of government expenditures and non-tax revenues, a cut in today's taxes, must be matched by a corresponding increase in the present value of future taxes. But an argument was that the present value of taxes would not change as long as the present value of spending did not change. Therefore, the substitution of a budget deficit for current taxes (or any other re-arrangement of timing of taxes) has no impact on the aggregate demand for goods. In this sense, budget deficits and taxation have equivalent effects on the economy.

Put in another way, the Ricardian Equivalent Theorem believe that, a decrease in the government's savings (that is a current budget deficit) leads to an offsetting increase in desired private saving, and to no change in desired national saving, in a closed economy; hence there is no effect on investment, and no burden of the public debt. And in an open economy there would also be no effect on the current account balance because desired private savings rises by enough to avoid having to borrow from abroad. Therefore, budget deficit will not cause current account deficits.

\section{The Neoclassical View of Budget Deficits}

The Neoclassical posits that there exist three central features that play an important role in determining the impact of budget deficits. They maintained that, first, the consumption of each individual is determined as the solution to an intertemporal optimization problem, where both borrowing and lending are permitted at the market rate of interest. Secondly is that individuals have finite lifespan; and thirdly that, market clearing are generally assumed in all periods. Much literature that builds upon Hall's (1978) formulation of the stochastic permanent income hypothesis that investigates the empirical validity of the neoclassical first feature. According to King (1983) and Hayashi (1985), states that consumers behave as though they solve an intertemporal optimization problem with access to perfect capital markets.

Despite numerous problems with estimation and interpretation, the evidence on balance supports the view that a sizable minority, say $20 \%$ of individuals fails to behave 
in a way that is consistent with unconstraint intertemporal optimization. The neoclassical second characteristic (finite lifespan) defines the central difference between the neoclassical and Ricardian frameworks. And the third characteristic (full employment) is the primary distinction between the neoclassical and Keynesian paradigms.

\section{The Keynesian View of Budget Deficits}

The Keynesian view differs from the neoclassical paradigm in two fundamental ways. First is that it allows for the possibility that some economic resources are unemployed. And secondly is that it presupposes the existence of large number of myopic, liquid constrained individuals.

In the simplest and most naïve Keynesian model, increasing the budget deficit by one dollar (\$1) causes output to expand by the inverse of the marginal propensity to save. The standard IS-LM analysis of monetary economies, this expansion of output raises the demand for money. If the money supply is fixed (that is the deficit is bond financed), interest rates must rise and private investment falls. This in turn reduces output and partially offsets the Keynesian multiplier effect.

Many traditional Keynesians argue that deficits need not crowd out private investment. Eisner suggests that increased aggregate demand changes the profitability of private investment and lead to a higher level of investment at any given rate of interest. Thus, deficits may actually stimulate aggregate saving and investment despite the fact that they raise interest rates. In Eisner's view, increased consumption is supplied from otherwise utilized resources

\subsection{Empirical Literature}

Nwanna and Umeh (2019) employed Ordinary Least Square (OLS) estimation technique coupled with Augmented Dickey Fuller (ADF) unit root test, Johansen Co-integration test and normality test to examine the effect of budget deficit on Nigeria's economic growth between 1981 and 2016. The results indicate that financing budget deficit through external debts has significant negative impact on Nigeria's economic growth while domestic debt has significant positive effect, but debt service has no effect on the economic growth. Therefore, the study suggests that external debts for financing budget deficit must be properly managed by reducing corruption, linkages and wastages in the system. Ezeanyeji, Imoagwu and Ejefobihi (2019) examined the relationship between public debt and inflation in Nigeria for the period 1981 to 2017. The Augmented DickeyFuller (ADF) test, co-integration test and Error Correction Model (ECM), were employed in the analysis. The results of the analyses revealed that public debt, exchange rate and money supply have positive and significant impact on inflation in Nigeria. Also, real GDP growth rate has negative and statistically insignificant impact on inflation in Nigeria.

Also, Ahmed and Alamdar (2018) investigate the effects of budget deficit and corruption on private sector investment in Pakistan. Annual time series data were used to examine the long run and short run relationship between the variables for the period between 1985 and 2015. Johansen and Juselious (1990) method was used for the 
cointegration test while Error Correction Model was applied for the short-run analysis. The results, among others show that budget deficit indeed crowds out private investment in Pakistan. Also, Noveski (2018) probe the impact of the budget deficit on Gross Domestic Product (GDP) per capita in Macedonia using a multiple regression model with data spanning from 1996 to 2015. The results indicate that budget deficit does not affect significantly the GDP per capita; thus, supporting the Ricardian equivalence theory. Similarly, Epaphra (2017) applied Vector Autoregression (VAR) - Vector Error Correction Model (VECM), and variance decomposition techniques to examine the relationship between budget deficits and selected macroeconomic variables in Tanzania with data spanning from 1966 to 2015. The results indicate that there is a significant negative relationship between real GDP, exchange rate, and budget deficit in Tanzania. Further analyses revealed that external financing of the budget deficit has been higher than domestic financing with its high servicing cost gulping funds that should have been used to finance development. Again, Paiko (2012) posits that prolong budget deficit in Nigeria could be responsible for the low private investment in the country due to its effect on the interest. To confirm this assertion, he conducted a study to assess the effect of budget deficit and government expenditure on private investment. Ordinary Least Squares (OLS) regression analysis was employed to analyse the secondary data spanning from 1990 to 2007. The results of the analyses show that both budget deficit and government expenditure have negative impact on the economy by crowding-out private investment. In the light of this finding, Paiko (2012) favours the financing of budget deficit through the capital market in order to avoid its crowding out effect.

Based on the literature review in this section, it is evident that several works have examined the macroeconomic effects of budget deficit in Nigeria in both the developed and the developing countries including Nigeria. However, the most recent of the studies covered the period between 1981 and 2017. The timeframe of previous studies seen by the researchers in the literature are shorter periods than the period of the present study. However, this study contributes to the current debate but differs from the previous studies by using a fairly large period of time from 1981 to 2019 in analyzing the macroeconomic effects of budget deficit in Nigeria.

\section{Methodology}

\subsection{Model Specification}

\section{Model I}

The first model seeks to examine the effects of budget deficit on economic growth as captured by growth rate of Gross Domestic Product. The modified model of Akinmulegun (2014) was to capture objective one (1) of this study; the following functional model were developed thus:

$\mathrm{GRGDP}=f(\mathrm{BD}, \mathrm{MS}, \mathrm{INF}, \mathrm{INT}, \mathrm{LF})$

The econometric form of the model can be expressed as: 
$\mathrm{GRGDP}_{\mathrm{t}}=\beta_{0}+\beta_{1} \mathrm{BD}_{\mathrm{t}}+\beta_{2} \mathrm{MS}_{\mathrm{t}}+\beta_{3} \mathrm{INF}_{\mathrm{t}}+\beta_{4} \mathrm{INT}_{\mathrm{t}}+\beta_{5} \mathrm{LF}_{\mathrm{t}}+\mu_{\mathrm{t}}$

Where;

GRGDP $=$ Growth rate of real gross domestic product

$\mathrm{BD}=$ Revenue minus government expenditure is taken as proxy for budget deficit. These are the most quantifiable in terms of data generation and as such should provide an acceptable approximation for fiscal policies in Nigeria.

MS = Money supply, measured as ratio of GDP

$\mathrm{INF}=$ Inflation rate, measured by annual year-on-year inflation rate

INT $=$ Interest rate measured in percentage

$\mathrm{LF}=$ Labour force participation rate,total (\% of total population ages $15+)$

$\beta_{0}$ is the constant

$\beta_{1}, \beta_{2}, \beta_{3}, \beta_{4}$ and $\beta_{5}$, are matrices of coefficient to be estimated, and

$\mu=$ Stochastic error term incorporated in any regression model based on the classical assumption of a linear regression model to account for variables omitted in the model. However, it is expected that $-\beta_{0}>0, \beta_{1}>0, \beta_{2}>0, \beta_{3}<0, \beta_{4}<0$ and $\beta_{5}>0$.

\section{Model I1:}

The second model aims to investigate the impact of budget deficit on private investment in Nigeria. The current study has employed and modified the model formulated by Asogwa and Okeke (2013) to capture objective two (2) of this study; the following functional model was developed thus:

$\mathrm{PRINV}_{\mathrm{t}}=f(\mathrm{BD}, \mathrm{MS}, \mathrm{INF})$

Where;

PRINV = Private investment (Gross Fixed Capital Formation) as a percentage of GDP

$\mathrm{BD}=$ Revenue minus government expenditure is taken as proxy for budget deficit.

MS = Money supply, measured as ratio of GDP

INF = Inflation rate, measured by annual year-on-year inflation rate

This equation (3) can be stated as an econometric equation thus:

$\mathrm{PRINV}_{\mathrm{t}}=\alpha_{0}+\beta_{1} \mathrm{BD}_{\mathrm{t}}+\alpha_{2} \mathrm{MS}_{\mathrm{t}}+\alpha_{3} \mathrm{INF}_{\mathrm{t}}+\mu$

For the other acronyms, $\alpha$ is constant, $\mu$ is error term and $\alpha_{1}, \alpha_{2}$, and $\alpha_{3}$, are the coefficients of the explanatory variables and $t$ is time period. However, it is expected that $-\alpha_{0}>0, \alpha_{1}$ $>0, \alpha_{2}>0$, and $\alpha_{3}<0$.

\section{Model II1:}

The third model aims to probe the effect of budget deficit on public investment. The model from the work of Ncanywa and Masoga (2018) were adopted and modified to capture objective three (3) of this study; the following functional model was developed thus: 
$\mathrm{PUINV}=f(\mathrm{BD}, \mathrm{MS}, \mathrm{INF})$

Where;

PUINV = Public investment measured as ratio government capital expenditure to GDP

$\mathrm{BD}=$ Revenue minus government expenditure is taken as proxy for budget deficit.

MS = Money supply, measured as ratio of GDP

INF = Inflation rate, measured by annual year-on-year inflation rate

The estimating form of equation (5) above is represented as:

$\mathrm{PUINV}_{\mathrm{t}}=\kappa_{0}+\kappa_{1} \mathrm{BD}_{\mathrm{t}}+\kappa_{2} \mathrm{MS}_{\mathrm{t}}+\kappa_{3} \mathrm{INF}_{\mathrm{t}}+\mu$

Where;

$\kappa 0$ is the constant term,

$\Upsilon_{1}-\kappa_{3}$ are estimation parameters,

$t$ is the time trend, and $\mu$ is the random error term. However, it is expected that $-\beta_{0}>0, \beta_{1}>0, \beta_{2}$ $>0, \beta_{3}<0, \beta_{4}<0$ and $\beta_{5}>0$.

\subsection{Analytical Procedure}

The study employed the Augmented Dickey Fuller (ADF) unit root test, and AutoRegressive Distributed Lag (ARDL) bounds co-integration approach developed by Pesaran, et al., (2001), in the analysis. The nature of data for the study was essentially secondary data over the 1981-2019. Datasets were drawn from Central Bank of Nigeria statistical Bulletin expressed in percentage. E-Views 9.0 was employed to estimate the model because of its user friendliness and reliability.

\section{Analysis of Result}

\subsection{Unit Root Test}

In order to test the stability of the time series of the study variables, both the Augmented Dickey Fuller (ADF) test is used to ascertain the stability of the time series. Since the nonstability of the time series leads to a spurious regression results, and therefore the tests were conducted for the variables. The result is presented as follow:

Table 4.1: Abridged ADF Unit Root Test for the Models

\begin{tabular}{|c|c|c|c|c|c|c|c|}
\hline \multirow[t]{2}{*}{ Model(s) } & \multirow[t]{2}{*}{ Variables } & \multirow{2}{*}{$\begin{array}{c}\text { ADF- } \\
\text { Statistic }\end{array}$} & \multicolumn{3}{|c|}{ Critical Value } & \multirow{2}{*}{$\begin{array}{c}\text { Order of } \\
\text { Integration }\end{array}$} & \multirow{2}{*}{$\begin{array}{c}\text { Durbin- } \\
\text { Watson } \\
\text { stat. }\end{array}$} \\
\hline & & & $1 \%$ & $5 \%$ & $10 \%$ & & \\
\hline \multirow{6}{*}{ Model I } & GRGDP & -4.118099 & -3.621023 & -2.943427 & -2.610263 & $1(0)$ & 2.497779 \\
\hline & $\mathrm{BD}$ & -6.525818 & -3.626784 & -2.945842 & -2.611531 & $1(1)$ & 1.933522 \\
\hline & MS & -5.619172 & -3.626784 & -2.945842 & -2.611531 & $1(1)$ & 1.949508 \\
\hline & INF & -5.892416 & -3.632900 & -2.948404 & -2.612874 & $1(1)$ & 2.173674 \\
\hline & INT & -9.559080 & -3.626784 & -2.945842 & -2.611531 & $1(1)$ & 2.196289 \\
\hline & LF & -6.000997 & -3.626784 & -2.945842 & -2.611531 & $1(1)$ & 2.001713 \\
\hline Model II & PRINV & -5.053669 & -3.621023 & -2.943427 & -2.610263 & $1(0)$ & 1.665960 \\
\hline
\end{tabular}




\begin{tabular}{|l|l|l|l|l|l|l|l|}
\hline \hline \multirow{5}{*}{ Model III } & BD & -6.525818 & -3.626784 & -2.945842 & -2.611531 & $1(1)$ & 1.933522 \\
\cline { 2 - 8 } & INF & -5.892416 & -3.632900 & -2.948404 & -2.612874 & $1(1)$ & 2.173674 \\
\cline { 2 - 8 } & MS & -5.619172 & -3.626784 & -2.945842 & -2.611531 & $1(1)$ & 1.949508 \\
\cline { 2 - 8 } & PUINV & -4.722458 & -3.646342 & -2.954021 & -2.615817 & $1(0)$ & 2.072257 \\
\cline { 2 - 8 } & BD & -6.525818 & -3.626784 & -2.945842 & -2.611531 & $1(1)$ & 1.933522 \\
\cline { 2 - 8 } & MS & -5.619172 & -3.626784 & -2.945842 & -2.611531 & $1(1)$ & 1.949508 \\
\cline { 2 - 8 } & INF & -5.892416 & -3.632900 & -2.948404 & -2.612874 & $1(1)$ & 2.173674 \\
\hline
\end{tabular}

Source: Author's Compilation (2021) from E-views 9 Output.

For the three models in Table 4.1 above, variables in the models exhibited different orders of integration when the ADF test is used. However, the ADF results indicated that Growth rate of real gross domestic product (GRGDP), private investment (PRINV) and public investment (PUINV) were stationary at level I(0). All other variables [(budget deficit (BD), money supply (MS), inflation rate (INF), interest rate (INT), labour force participation rate (LF)] became stationary at first differencing, indicating that the variables are integrated of order one (1). Then, we proceed with the bounds test as it can estimate variables both at level and of first order of integration (Pesaran, et al., 2001). Hence, to confirm the reliability of this result, the Durbin Watson statistic value for each variable is significant at approximately 2.00, which means, confirms the absence of autocorrelation problem in the time series data in the respective models. Hence, on the ADF test the condition for Johansen cointegration test is not met. This kind of conflict between the outcomes of the two tests is common in practice (Shahbaz \& Rahman, 2012). According to Ouattara (2004), the bounds test approach is valid only when the variables are a mix of $\mathrm{I}(0)$ and $\mathrm{I}(1)$. Since the unit root tests indicated that most of the series variables have a different order of integration, more robust cointegration analysis is then tested using the ARDL bounds testing approach.

\subsection{Bound Test}

One of the basic reasons for estimating an ARDL model is to utilise it as a platform for applying the Bound test. The model utilises both the $F$ - and $t$-statistics to test the significance of lagged levels of the variables in a univariate error correction system when it is unclear if the data generating process underlying a time series is trend or first difference stationary. The result for this Bound test is given as follows:

Table 4.2: Result for the Bound Test for the Models

\begin{tabular}{|c|c|c|c|c|c|c|}
\hline \multirow[t]{2}{*}{ Models } & \multirow[t]{2}{*}{ Functional Form } & \multirow{2}{*}{$\begin{array}{c}\text { F-statistic } \\
\text { Value }\end{array}$} & \multirow[t]{2}{*}{$\mathbf{K}$} & \multicolumn{3}{|c|}{ Critical Values Bounds } \\
\hline & & & & Significance & 10 Bound & II Bound \\
\hline \multirow{4}{*}{ Model I } & \multirow{4}{*}{$\begin{array}{l}\mathrm{GRGDP}_{\mathrm{t}}=f(\mathrm{BD}, \mathrm{MS}, \mathrm{INF}, \\
\mathrm{INT}, \mathrm{LF})\end{array}$} & \multirow{4}{*}{6.447235} & \multirow{4}{*}{5} & $10 \%$ & 2.26 & 3.35 \\
\hline & & & & $5 \%$ & 2.62 & 3.79 \\
\hline & & & & $2.5 \%$ & 2.96 & 4.18 \\
\hline & & & & $1 \%$ & 3.41 & 4.68 \\
\hline \multirow{4}{*}{ Model II } & \multirow{4}{*}{$\mathrm{PRINV}_{\mathrm{t}}=f(\mathrm{BD}, \mathrm{MS}, \mathrm{INF})$} & \multirow{4}{*}{6.621616} & \multirow{4}{*}{3} & $10 \%$ & 2.72 & 3.77 \\
\hline & & & & $5 \%$ & 3.23 & 4.35 \\
\hline & & & & $2.5 \%$ & 3.69 & 4.89 \\
\hline & & & & $1 \%$ & 4.29 & 5.61 \\
\hline Model III & PUINV $_{\mathrm{t}}=f(\mathrm{BD}, \mathrm{MS}, \mathrm{INF})$ & 6.553027 & 3 & $10 \%$ & 2.72 & 3.77 \\
\hline
\end{tabular}




\begin{tabular}{|l|l|l|l|c|c|c|}
\hline \hline & \multirow{4}{*}{} & & $5 \%$ & 3.23 & 4.35 \\
\cline { 4 - 6 } & & & $2.5 \%$ & 3.69 & 4.89 \\
\cline { 4 - 6 } & & & $1 \%$ & 4.29 & 5.61 \\
\hline
\end{tabular}

Source: Author's Compilation (2021) from E-views 9 Output.

For the three models, the F-statistics determined that the greater value was found to be greater than the critical values of $\mathrm{I}(0)$ (Lower bound) and I(1) (Upper bound) bounds. This implies that there is a co-integration among the variables in the respective models. Table 4.2 above presents cointegration results of the bounds testing. However, the calculated F-statistics is 6.447235, 6.621616 and 6.553027 which is greater than the lower bounds critical and the upper critical at all level of significant. Therefore, there is cointegration amongst the variables, meaning in the long run the variables are co-moved (Pesaran, et al., 2001). As a result, the null hypothesis of no long-run relationship shall be rejected based on this empirical finding. This implies the existence of a cointegrated relationship between deregulation of downstream oil sector and other economic growth, standard of living and inflation in the models. Therefore, the ARDL models fulfill the assumptions of normality, $\mathrm{ARCH}$, and functional forms of models. The findings note that error terms are normally distributed, there is no evidence of $\mathrm{ARCH}$, and models are well articulated. This confirms that our findings are more reliable and consistent than previous ones. The implication of this result is that deviation may occur among the variables but that is for the short run whereas equilibrium holds in the long-run for them. Meanwhile, having established the existence of a long-run relationship, we then used the Akaike Information Criteria (AIC) for the models selection. In total, 2048 ARDL model specifications were considered. An ARDL $(2,1,0,3,0,0 ; 2,0,0,0$; and 1, 2, 0, 0) was finally selected based on the AIC in the respective models. Figure 4.1, 4.2 and 4.3 probe how well some other specifications performed.

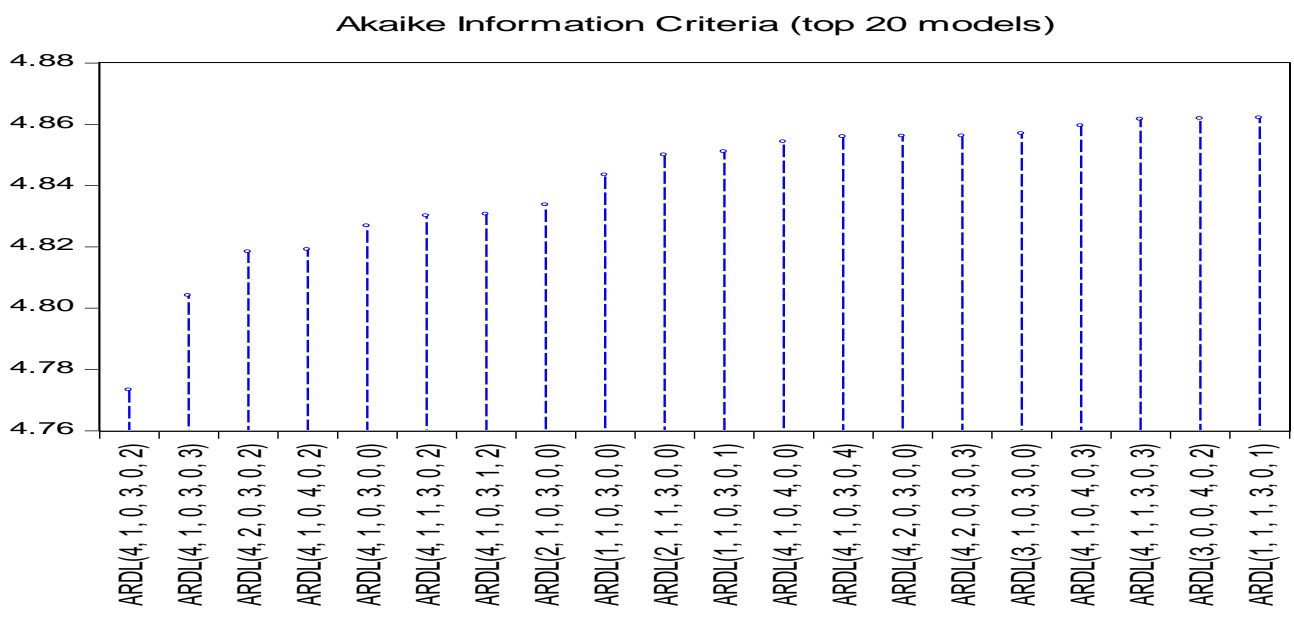

Figure 4.1: Top 20 Models (based on AIC) for Model I 


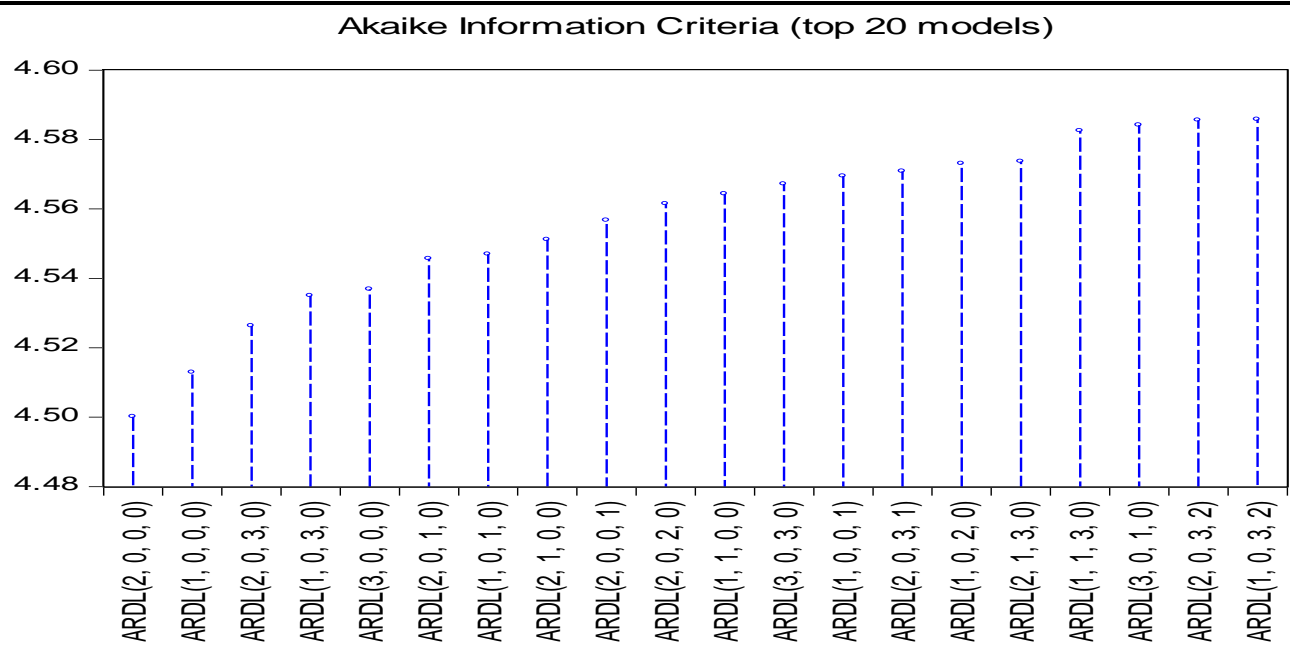

Figure 4.2: Top 20 Models (based on AIC) for Model II

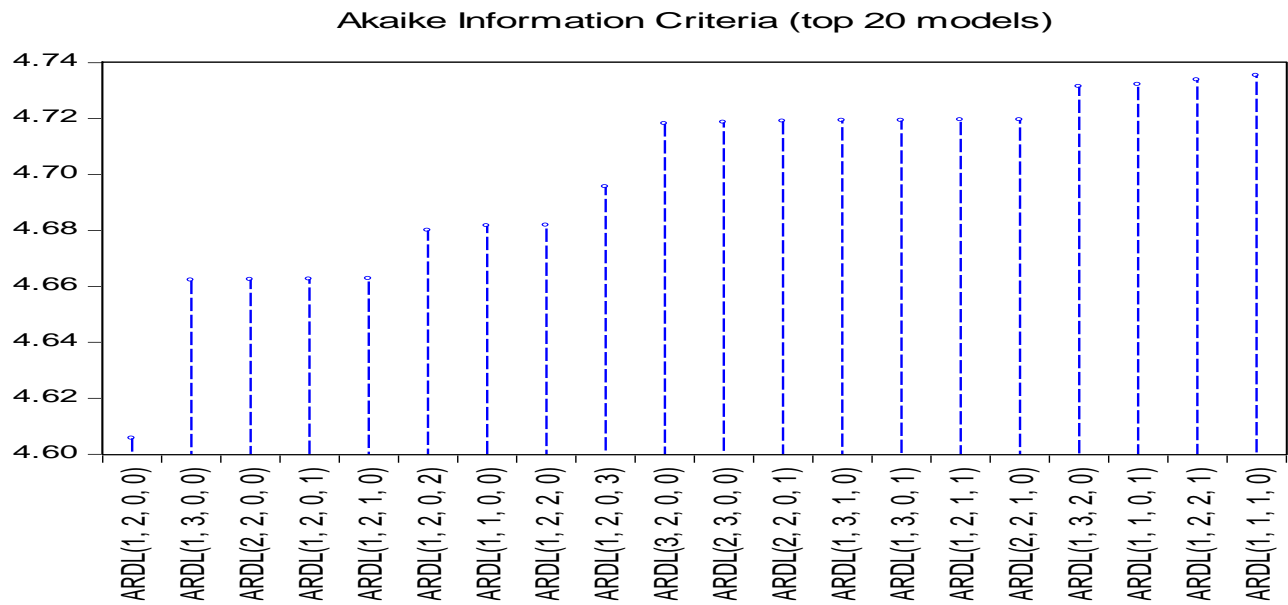

Figure 4.3: Top 20 Models (based on AIC) for Model III

\subsection{Coefficient of Long-run Adjustment}

The findings for the long-run coefficient of the variables under investigation are estimated using the optimal ARDL selection according to the AIC criterion. The long-run elasticities and its corresponding coefficients of the models are given below.

Table 4.3: Long-run Adjustment Coefficients based on ARDL Approach for the Models

\begin{tabular}{|c|c|c|c|c|c|}
\hline \multirow{7}{*}{$\begin{array}{l}\text { Dependent Variable: } \\
\text { GRGDP }\end{array}$} & Regressor & Coefficient & Std. Error & t-Statistic & Prob. \\
\hline & $\mathrm{BD}$ & 3.242857 & 1.040083 & 3.117881 & $0.0048^{*}$ \\
\hline & MS & -0.867100 & 0.413910 & -2.094902 & $0.0474^{*}$ \\
\hline & INF & -0.301953 & 0.086913 & -3.474200 & $0.0021^{*}$ \\
\hline & INT & 0.869375 & 0.229692 & 3.784964 & $0.0010^{*}$ \\
\hline & LF & -0.044937 & 0.041396 & -1.085532 & 0.2889 \\
\hline & $\mathrm{C}$ & 18.193392 & 9.811995 & 1.854199 & 0.0766 \\
\hline $\begin{array}{l}\text { Model I: } \\
\text { ARDL }(2,1,0,3,0,0)\end{array}$ & \multicolumn{5}{|c|}{$\begin{array}{l}\text { R-squared }=0.662556 \\
\text { Adjusted R-squared }=0.541076 \\
\text { F-statistics }=5.454036 \\
\text { Prob (F-statistics) }=0.000361 \\
\text { Durbin Watson }=1.973231\end{array}$} \\
\hline \multirow{2}{*}{$\begin{array}{l}\text { Dependent Variable: } \\
\text { PRINV }\end{array}$} & $\mathrm{BD}$ & -0.679806 & 0.496193 & -1.370045 & 0.1808 \\
\hline & MS & 0.072291 & 0.182963 & 0.395111 & 0.6956 \\
\hline
\end{tabular}




\begin{tabular}{|c|c|c|c|c|c|}
\hline \multirow[b]{3}{*}{$\begin{array}{l}\text { Model II:ARDL } \\
(2,0,0,0)\end{array}$} & INF & -0.015406 & 0.041527 & -0.370977 & 0.7133 \\
\hline & $\mathrm{C}$ & 10.510240 & 3.863542 & 2.720364 & $0.0107^{*}$ \\
\hline & \multicolumn{5}{|c|}{$\begin{array}{l}\text { R-squared }=0.505571 \\
\text { Adjusted R-squared }=0.423167 \\
\text { F-statistics }=6.135219 \\
\text { Prob (F-statistics) }=0.000500 \\
\text { Durbin Watson }=1.945269\end{array}$} \\
\hline \multirow{4}{*}{$\begin{array}{l}\text { Dependent Variable: } \\
\text { PUINV }\end{array}$} & $\mathrm{BD}$ & 2.733133 & 0.717479 & 3.809356 & $0.0007^{*}$ \\
\hline & MS & -0.472293 & 0.179466 & -2.631653 & $0.0135^{*}$ \\
\hline & INF & 0.150294 & 0.053408 & 2.814064 & $0.0087^{*}$ \\
\hline & $C$ & 19.238446 & 3.898044 & 4.935410 & $0.0000^{*}$ \\
\hline $\begin{array}{l}\text { Model III: } \\
\text { ARDL }(1,2,0,0)\end{array}$ & \multicolumn{5}{|c|}{$\begin{array}{l}\text { R-squared }=0.480750 \\
\text { Adjusted R-squared }=0.373319 \\
\text { F-statistics }=4.474967 \\
\text { Prob (F-statistics) }=0.002533 \\
\text { Durbin Watson }=2.016601\end{array}$} \\
\hline
\end{tabular}

Source: Author's Compilation (2021) from E-views 9 Output.

Note: ${ }^{*}$ denote statistical significance at the $1 \%$ and $5 \%$ levels.

Thediscussion of results was based on research questions stated in chapter one.

\subsubsection{Discussion of Results based on Research Objective One}

To investigate the impact of budget deficit on the growth of GDP in Nigeria, the Table 4.3 , model one (1) probe the abridged presentation of long-run adjustment of parameters of the $\operatorname{ARDL}(2,1,0,3,0,0)$ for model one (1).

Having found the evidence of the long-run relationship through the bounds testing, the coefficients of long run are projected. The result established that the constant term has positive value of 18.193392, even though it does not have any economic meaning; it meets our a priori expectation. This indicated that the value is positive but statistically insignificant with p-value of 0.0 .0766 which is greater than 0.05 . Therefore, this shows that regardless of change on the explanatory variables, the economic growth will be improved in the model.

Budget deficit (BD) sometimes called debt-to-GDP ratio is a measure of debt increase/decrease as percentage of GDP. From the results, the study observed statistically significant and positive impact on economic growth in Nigeria. In other word, budget deficit has significant impact on economic growth in Nigeria. This implies that a unit increase in budget deficit will result to $324.28 \%$ increases in economic growth (GRGDP) in Nigeria. Therefore, increase in government deficit spending does not harm on economic growth or performance such as crowding-out investment in Nigeria as stipulated by Keynes. Though, the magnitude of increase in economic growth (324.28\%) as a result of increase in government debt is small. This finding is in contrary with the views of David Ricardo who stipulated that government budget deficit should be reduced to avoid economic drawback.

Interest rate (INT) is one of the important macroeconomic variables, which is directly related to economic growth. Generally, interest rate is considered as the cost of capital, which means the price paid for the use of money for a period of time. From the 
view point of borrowers, interest rate is the cost of borrowing while lender's view it as fee charged for lending. However, from the estimated results above, the study probe that interest rate (INT) is significant and positively related to economic growth (GRGDP) instead of the expected inverse relationship. This result presupposes that a unit increases in interest rate is associated with $86.93 \%$ increase in economic growth which is against the apriori expectation. In real sense, increases in interest rate simply mean increase in cost of borrowing thereby making investment financing expensive. This in turn should lead to a fall in the level of economic activities and growth. However, the positive effect could be as a result of poor data generation in Nigeria or the attitude of lenders lending about $75 \%$ of their deposit to importer who are willing to borrow at higher rate.

In the contrary to the above findings, the regression results also revealed a negative and significant effect of money supply (MS) on economic growth in Nigeria. This suggests that a percentage increase in real money supply (MS) is directly related to $86.7 \%$ decrease in economic growth in Nigeria. Hence, in view of the findings and the magnitude of the effect of money supply (MS) on economic growth in Nigeria, any authority that encourage the restriction of expansionary monetary policy could end up retarding performance and as well volume of transaction in the economy.

The coefficient of inflation (INF) is inversely related to economic growth in Nigeria. However, inflation has significant and negative effect on economic growth in Nigeria. This means that a unit increase in inflation rate lead to $30.19 \%$ decline in economic growth in Nigeria. Given the result, the authorities should be in their effort to control for the rate of inflation rate in Nigeria. Rise in inflation signifies fall in value of money and this situation could leads to decline in the purchasing power with a corresponding increase in interest rates. The increase in the parameter could be tantamount to increase in cost of goods and services. Consequently, the level of economic activities will fall, and consumers will have to shell out more money for the same goods. Furthermore, there exist a negative relationship between labour force (LF) and economic growth in Nigeria. This implies that a unit increase in labour force causes about $4.49 \%$ increases in economic growth in Nigeria. Hence, the value of the labour force is positive but insignificantly impact on economic growth in Nigeria.

The model summary gives the value of coefficient determination (R-squared) which is the measure of the extent to which the predictor variables influence the dependent variable. The R-square value from the table is 0.662556 which explains that, holding other variables constant, the growth rate of RGDP, budget deficit, money supply, inflation rate, interest rate and labour force participation rate account for $66.25 \%$ of the variability in the economic growth of the country. This therefore shows that, other variables which were not considered in this study would account for $33.75 \%$ of the variability in the Nigeria's economic growth. Also, the table gives the adjusted R square which is the measure of the reliability of the results. The value as the table indicates is 0.541076 illustrating that, the study results are $54.10 \%$ reliable. Thus, based on this, the model results are significant and reliable in explaining the influence of the predictor variables to the dependent variable. Complementing this is the F- statistics with 5.454036 with probability values of 0.000361 . This is highly significant at the 5 percent levels; thus, 
lending credence to the conclusion that the entire model has goodness of fit. To investigate the presence of autocorrelation in the residual (prediction errors) from a regression analysis, we employed Durbin Watson test. However, the essence of this test is to avoid biased result because, the presence of autocorrelation could lead to underestimation of the standard error of the coefficient and the predictors may seem to be significant when they may not. The value Durbin-Watson is 1.973231 as it is contained in the Table 4.3 above. However, taken a glance on the result, we may suspect evidence of autocorrelation which suggest that the residual of one period may be correlated with the residual of any previous periods.

\subsubsection{Discussion of Results based on Research Objective Two (2)}

To evaluate the effect of budget deficit on private investment in Nigeria, the Table 4.3, model two (2) indicates the abridged presentation of long-run adjustment of parameters of the ARDL $(2,0,0,0)$ for model two (2).

The result of the estimated model shows that the coefficient of the constant is 10.510240. It indicates that when other variables are held constant, the mean value of the private investment will be $1051.024 \%$. By implication, the model suggests that a unit change in explanatory variables has the potential to induce about $1051.024 \%$ change in the response of private investment in the same direction. In like manner, further investigation show that money supply has positive but insignificant effect on private investment in Nigeria. Specifically, a 1 unit increase in money supply leads to $7.22 \%$ improvement in private investment all other factors being equal.

The coefficient of the budget deficit is negative and conforms to a priori expectation which says that the higher the budget deficit overtime, the lower the rate at which private individuals will embark on investment ventures. By implication, a unit increases in budget deficit causes about $67.98 \%$ declines in private investment in Nigeria. Similarly, the coefficient value of the inflation rate is negative, and it does not conform to a priori expectation which states that the higher the inflation rate, the higher the rate of investment, hence it is expected that there should exist a positive relationship between the inflation rate and the private investment in Nigeria. By implication however, on the average, a $1 \%$ increase in the inflation rate would lead to a $1.54 \%$ decrease in private investment in Nigeria which is not in line with theory. As the general price level in the economy rises, businessmen try to exploit that opportunity by producing more goods and rendering more services to the members of the public in other to accumulate more money which would be used for reinvestment. Thus, inflation rate has negative and insignificant effect on private investment, and it is not in conformity with theory. This could be a case of hyperinflation (above 10\%) that raises the interest rate on loanable funds, thereby reducing the demand for investment funds and contributes negatively to the growth of an economy. However, some optimal level of inflation can help spur economic growth especially mild or creeping inflation rate of less than $6 \%$ (Drazen, 1979). Furthermore, the negative sign implies that inflation rate has been one of the constraints facing private investment in developing countries like Nigeria by generating higher cost 
of production to private firms as well as creating uncertain investment climate which impinge on private sector.

However, the value of determination R-squared obtained is 0.505571 . This probe that the explanatory variables included in our model accounts for $50.56 \%$ movement in private investment in Nigeria while the remaining $49.44 \%$ unexplained variations is due to other extraneous factors that also necessarily accounts for the movement in private investment in Nigeria which is explained by the stochastic term. The implication is that the models do not suffer from any misspecification error. Complementing this is the Fstatistics with 6.135219 with probability values of 0.000500 . This is highly significant at the 5 percent levels; thus, lending credence to the conclusion that the entire model has goodness of fit. Finally, as a rule of thumb, if Durbin-Watson statistic is less than 2.0, there is an indication of autocorrelation among the variables, but higher value suggests that autocorrelation is not much severe. From the above table, the D-W statistic is 1.94 that is; less than the required value for D-W statistic (1.8 is less than 2.0). By implication, the successive error terms on average are close to one another in value and therefore, there exist (with negligible concerned) an element of autocorrelation in the series.

\subsubsection{Discussion of Results based on Research Objective Three (3)}

To determine the effect of budget deficit on public investment in Nigeria, the Table 4.3, model three (3) indicates the abridged presentation of long-run adjustment of parameters of the ARDL $(1,2,0,0)$ for model three (3).

The regression results show that the intercept of the model is 19.238446. This implies that when the measures of independent variables are fixed or held constant, public investment will increased by $1923.8 \%$. Also, it established that the value is positive and statistically significant with p-value of 0.0000 which is less than $0.05 \%$ level of significant. Also, budget deficits were found to have unexpected positive and significant impact on public investment. It probes that $1 \%$ change in budget deficits contributes $273.3 \%$ positive change in the public investment in Nigeria. It shows that the expenditure that surpassed the revenue was put on productive ventures. This was expected as previous deficits would imply more expenditure than revenue which is expected to impact positively on the public investment as well as growth of an economy. This could on the other hand imply that budget deficits crowds-out public-private sector investment as government borrows extensively from the domestic financial institutions, pushing up the interest rate on investment fund required by the private sector which today considered by many economies as the engine of growth and hence need enabling environment on which to thrive. Again, the inflation rate (INF) that was used to also measure the macroeconomic stability of the country showed the unexpected positive value and significant affects public investment in Nigeria. The regression results probe that $1 \%$ change in inflation contributes to $15.02 \%$ increase in public investment in Nigeria. In the contrary, the money supply (MS) exhibited negative value but has a significant impact on public investment in Nigeria. The result indicates that $1 \%$ increase in money supply contributes to $47.2 \%$ decline in public investment in Nigeria. 
In the same vein, the R-squared is the summary measure that tells us how well the sample regression line fits the data. From the model three above, $\mathrm{R}^{2}$ of 0.480750 means showed that having removed the influence of the explanatory variables, the dependent variable is still explained by the equation with $48.07 \%$, and the remaining $51.93 \%$ was explained by variables not included in the model. The adjusted $\mathrm{R}^{2}$ takes account of a greater number of regressors if included and it still explains $37.33 \%$ variation in the dependent variable. Coincidentally, the goodness of fit of the regression remained too low after adjusting for the degree of freedom. The $f$-statistics of 4.474967 , which is a measure of the joint significance of the explanatory variables, is found to be statistically significant at 1 percent level as indicated by the corresponding probability value of 0.002533. This indicates that the model is of good fit and significant. The Durbin-Watson statistics in model two is 2.016601, which reveals to us that there is absence of autocorrelation between the dependent variable and independent variables in Nigeria.

\subsection{Short-run Adjustment}

The existence of cointegrated relationship among the variables provides more evidence for the estimation of ARDL (CointEq(-1)) that is, Error Correction Model (ECM-1)in the respective models with the view to estimate the short-run dynamics. The estimated ECM-1 for these models is shown in Table 4.4 below.

Table 4.4: Coefficients of Short-run Adjustment based on ARDL Approach for the Models

\begin{tabular}{|c|c|c|c|c|c|}
\hline \multirow{10}{*}{$\begin{array}{l}\text { Dependent Variable: } \\
\text { GRGDP }\end{array}$} & Variable & Coefficient & Std. Error & t-Statistic & Prob. \\
\hline & D(GRGDP(-1)) & -0.194203 & 0.140765 & -1.379625 & 0.1810 \\
\hline & $\mathrm{D}(\mathrm{BD})$ & 1.532835 & 0.366454 & 4.182889 & $0.0004^{*}$ \\
\hline & $\mathrm{D}(\mathrm{MS})$ & -0.570454 & 0.179377 & -3.180186 & $0.0042^{*}$ \\
\hline & D(INF) & -0.041132 & 0.030828 & -1.334222 & 0.1952 \\
\hline & $\mathrm{D}$ (INF) & -0.081054 & 0.036416 & -2.225794 & $0.0361^{*}$ \\
\hline & $\mathrm{D}$ (INF) & 0.150515 & 0.030464 & 4.940826 & $0.0001^{*}$ \\
\hline & $\mathrm{D}(\mathrm{INT})$ & 0.571950 & 0.183505 & 3.116819 & $0.0049^{*}$ \\
\hline & $\mathrm{D}(\mathrm{LF})$ & -0.029564 & 0.026248 & -1.126300 & 0.2717 \\
\hline & CointEq(-1) & -0.657886 & 0.161146 & -4.082556 & $0.0005^{*}$ \\
\hline $\begin{array}{l}\text { Selected Model I: } \\
\text { ARDL }(2,1,0,3,0,0)\end{array}$ & \multicolumn{5}{|c|}{$\begin{array}{l}\text { Cointeq }=\text { GRGDP }-\left(3.2429^{*} \mathrm{BD}-0.8671^{*} \mathrm{MS}-0.3020^{*} \mathrm{INF}+0.8694^{*} \mathrm{INT}-\right. \\
\left.0.0449^{*} \mathrm{LF}+18.1934\right)\end{array}$} \\
\hline \multirow{4}{*}{$\begin{array}{l}\text { Dependent Variable: } \\
\text { PINV }\end{array}$} & $\mathrm{D}(\mathrm{PINV}(-1))$ & 0.193599 & 0.135679 & 1.426885 & 0.1639 \\
\hline & $\mathrm{D}(\mathrm{BD})$ & -0.385649 & 0.277880 & -1.387825 & 0.1754 \\
\hline & $\mathrm{D}(\mathrm{MS})$ & 0.041010 & 0.104178 & 0.393654 & 0.6966 \\
\hline & $\mathrm{D}$ (INF) & -0.008739 & 0.022847 & -0.382517 & 0.7048 \\
\hline \multirow{2}{*}{$\begin{array}{l}\text { Selected Model II: } \\
\text { ARDL }(2,0,0,0)\end{array}$} & CointEq(-1) & -0.567293 & 0.115925 & -4.893614 & $0.0000^{*}$ \\
\hline & \multicolumn{5}{|c|}{ Cointeq $=$ PINV $-\left(-0.6789^{*} \mathrm{BD}+0.0723^{*} \mathrm{MS}-0.0154^{*} \mathrm{INF}+10.5102\right)$} \\
\hline \multirow{4}{*}{$\begin{array}{l}\text { Dependent Variable: } \\
\text { PUNV }\end{array}$} & $\mathrm{D}(\mathrm{BD})$ & 0.571191 & 0.347676 & 1.642884 & 0.1112 \\
\hline & $\mathrm{D}(\mathrm{BD}(-1))$ & -0.707081 & 0.372277 & -1.899342 & 0.0675 \\
\hline & D(MS) & -0.304199 & 0.142488 & -2.134914 & $0.0413^{*}$ \\
\hline & $\mathrm{D}$ (INF) & 0.096803 & 0.029256 & 3.308860 & $0.0025^{*}$ \\
\hline \multirow{2}{*}{$\begin{array}{l}\text { Selected Model III: } \\
\text { ARDL }(1,2,0,0)\end{array}$} & CointEq(-1) & -0.644090 & 0.144314 & -4.463121 & $0.0001^{*}$ \\
\hline & \multicolumn{5}{|c|}{ Cointeq(-1) $=$ PUINV $-\left(2.7331^{*}\right.$ BD-0.4723*MS+ 0.1503*INF+ 19.2384) } \\
\hline
\end{tabular}

Source: Author's Compilation (2021) from E-views 9 Output

Note: * denote statistical significance at the $1 \%$ and $5 \%$ levels. 
Having examined the nature of the long run relationship between budget deficit and its determinant variables, the error correction model [CointEq(-1)] was employed to determine the nature of the short run adjustment process towards the long run equilibrium state. It is noteworthy that the CointEq(-1) that is, error correction model (ECM), which is the residual value, is negative and significant in the model one. The error correction term shows that over $65.78 \%$ of the error associated with the short run adjustment mechanism is being corrected per period in the model one (1). This further probe the system has a relatively high adjustment speed and could also converge to its equilibrium state when acted upon by external forces.

From the empirical evidence of model II, the error correction estimates for the short-run dynamics is rightly signed with negative coefficient value of -0.567293 and absolute t-statistics value -4.893614 coupled with 0.0000 probability value. These estimates confirmed the long-run equilibrium condition evidenced among the variables included in the model and it further suggests that $56.7 \%$ of the deviations or disequilibrium in private investment from the previous shocks will converge back to the long-run equilibrium in the current period. In addition, the speed of adjustment suggested a moderate convergence to the equilibrium state following the short-run shocks.

Furthermore, the estimate of short-run dynamics of model III probe the coefficient of ECM-1 is negative and statistically significant in the model with a probability value of 0.0001. This result confirms the convergence of short-run to the long-run equilibrium. The coefficient is approximately -0.644090 , indicating that, $64.4 \%$ of the deviations or disequilibrium in public investment from the previous shocks will converge back to the long-run equilibrium in the following period. In relation to the relative adjustment, the speed of adjustment shows a very strong convergence towards the equilibrium period within the system. This implies that the adjustment to restore long-run equilibrium is reasonably high.

\subsection{Diagnostics and Stability Test for ARDL Models}

To ensure the robustness and stability of the model, several diagnostic tests are conducted with view to determining the validity of the findings. It is worth noting that the presence of regression pathologies such as serial correlation test, heteroskedasticity test, normality test, ARCH Test (Autoregressive Heteroskedasticity Test), model Specification Test (Ramsey RESET Test) and CUSUM and CUSUMSQ test, respectively. The estimated result from each diagnostic test is presented as given below:

Table 4.6: Diagnostic Checking for the Models

\begin{tabular}{|l|l|c|c|c|c|}
\hline Model (s) & Test Type & Statistic & Value & Prob. & Remarks \\
\hline \multirow{3}{*}{ Model I } & $\begin{array}{l}\text { SerialCorrelation (Breush- } \\
\text { Godfrey Serial Correlation } \\
\text { LM Test) }\end{array}$ & F-statistic & 2.189465 & 0.1444 & No serial correlation \\
\cline { 2 - 6 } & $\begin{array}{l}\text { Heteroskedasticity Test } \\
\text { (Breush-Pagan-Godfrey) }\end{array}$ & F-statistic & 0.757449 & 0.7037 & No heteroscedasticity \\
\hline
\end{tabular}




\begin{tabular}{|c|c|c|c|c|c|}
\hline & $\begin{array}{l}\text { ARCH Test (Autoregressive } \\
\text { Heteroskedasticity Test) }\end{array}$ & F-statistic & 0.782162 & 0.3833 & No ARCH effect \\
\hline & $\begin{array}{l}\text { Model Specification Test } \\
\text { (Ramsey RESET Test) }\end{array}$ & F-statistic & 1.116831 & 0.3054 & $\begin{array}{c}\text { Model Specification } \\
\text { well specified }\end{array}$ \\
\hline & $\begin{array}{l}\text { Normality Test (Jarque-Bera } \\
\text { Statistics) }\end{array}$ & $\begin{array}{l}\text { Jarque-Bera } \\
\text { Statistics }\end{array}$ & 0.829943 & 0.660359 & $\begin{array}{c}\text { Normally distributed } \\
\text { residuals }\end{array}$ \\
\hline \multirow{5}{*}{ Model II } & $\begin{array}{l}\text { SerialCorrelation (Breush- } \\
\text { Godfrey Serial Correlation } \\
\text { LM Test) }\end{array}$ & F-statistic & 0.385730 & 0.6835 & No serial correlation \\
\hline & $\begin{array}{l}\text { Heteroskedasticity Test } \\
\text { (Breush-Pagan-Godfrey) }\end{array}$ & F-statistic & 0.500672 & 0.7732 & No heteroscedasticity \\
\hline & $\begin{array}{l}\text { ARCH Test (Autoregressive } \\
\text { Heteroskedasticity Test) }\end{array}$ & F-statistic & 0.190235 & 0.6656 & No ARCH effect \\
\hline & $\begin{array}{l}\text { Model Specification Test } \\
\text { (Ramsey RESET Test) }\end{array}$ & F-statistic & 0.938770 & 0.3406 & $\begin{array}{c}\text { Model Specification } \\
\text { well specified }\end{array}$ \\
\hline & $\begin{array}{l}\text { Normality Test (Jarque-Bera } \\
\text { Statistics) }\end{array}$ & $\begin{array}{l}\text { Jarque-Bera } \\
\text { Statistics } \\
\end{array}$ & 0.319354 & 0.852419 & $\begin{array}{l}\text { Normally distributed } \\
\text { residuals }\end{array}$ \\
\hline \multirow{5}{*}{ Model III } & $\begin{array}{l}\text { SerialCorrelation (Breush- } \\
\text { Godfrey Serial Correlation } \\
\text { LM Test) }\end{array}$ & F-statistic & 0.793594 & 0.4625 & No serial correlation \\
\hline & $\begin{array}{l}\text { Heteroskedasticity Test } \\
\text { (Breush-Pagan-Godfrey) }\end{array}$ & F-statistic & 4.201435 & 0.0837 & No heteroscedasticity \\
\hline & $\begin{array}{l}\text { ARCH Test (Autoregressive } \\
\text { Heteroskedasticity Test) }\end{array}$ & F-statistic & 0.039700 & 0.8433 & No ARCH effect \\
\hline & $\begin{array}{l}\text { Model Specification Test } \\
\text { (Ramsey RESET Test) }\end{array}$ & F-statistic & 0.126833 & 0.7244 & $\begin{array}{c}\text { Model Specification } \\
\text { well specified }\end{array}$ \\
\hline & $\begin{array}{l}\text { Normality Test (Jarque-Bera } \\
\text { Statistics) }\end{array}$ & $\begin{array}{l}\text { Jarque-Bera } \\
\text { Statistics }\end{array}$ & 3.926099 & 0.140430 & $\begin{array}{l}\text { Normally distributed } \\
\text { residuals }\end{array}$ \\
\hline
\end{tabular}

Source: Author's Compilation (2021) from E-views 9 Output.

The diagnostic tests showed that the models are free of serial correlation problems; the model has no ARCH effects and therefore has no volatility of the series. Thus, the GARCH variance series shows that it can be used as a measure of real effective exchange rate volatility, the residual is normally distributed, there is no heteroscedasticity problem, and there is no functional form misspecification in the models. This gives us assurance that the results from the models are reliable, efficient and will be suitable for forecasting and policy and decision making. Finally, the decision rule guiding this test is that, if the plots of the CUSUM and CUSUMSQ statistics stay within the critical bounds of $5 \%$ level of significance, then the model coefficients are stable and desirable; otherwise, the model is rejected. To show the output of this test, they are depicted below in the form of graphical presentation. 
Figure 4.4a: Plot of Cumulative Sum (CUSUM) of Recursive Residuals for Model I

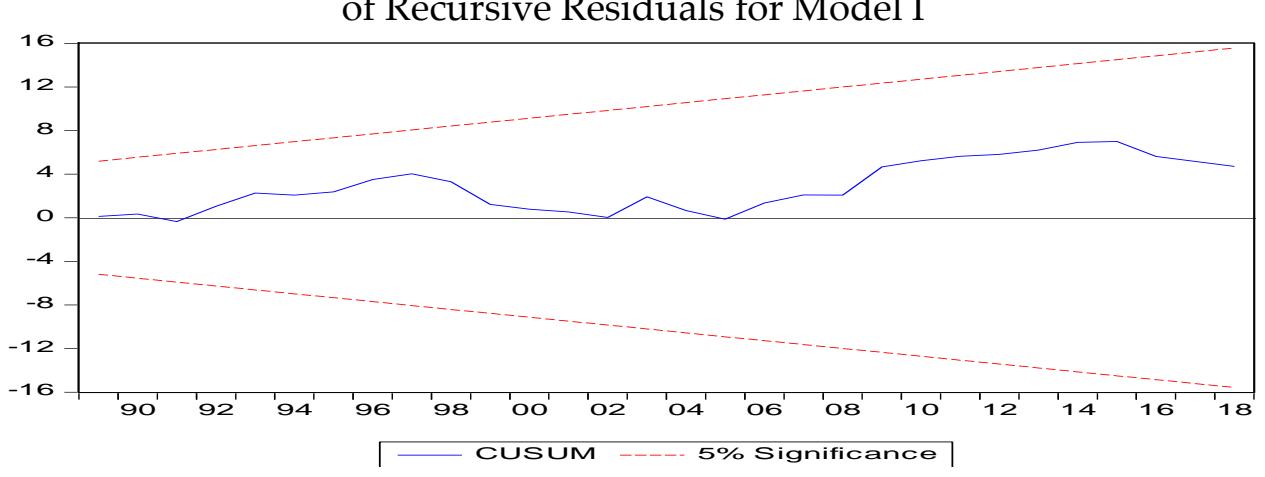

Figure 4.4b: Plot of Cumulative Sum of Squares (CUSUMQ)

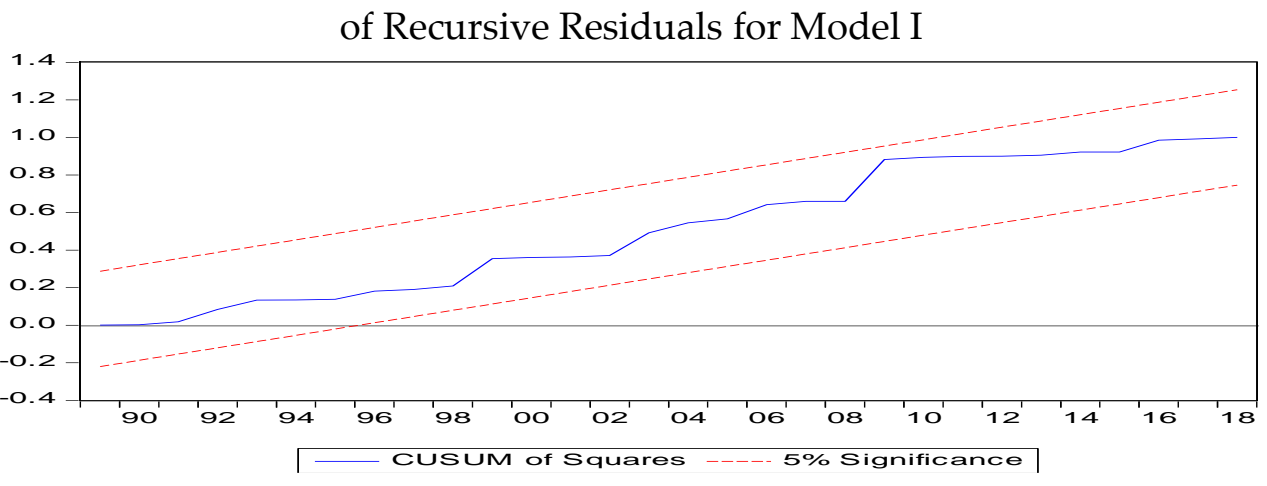

Figure 4.5a: Plot of Cumulative Sum (CUSUM) of Recursive Residuals for Model II

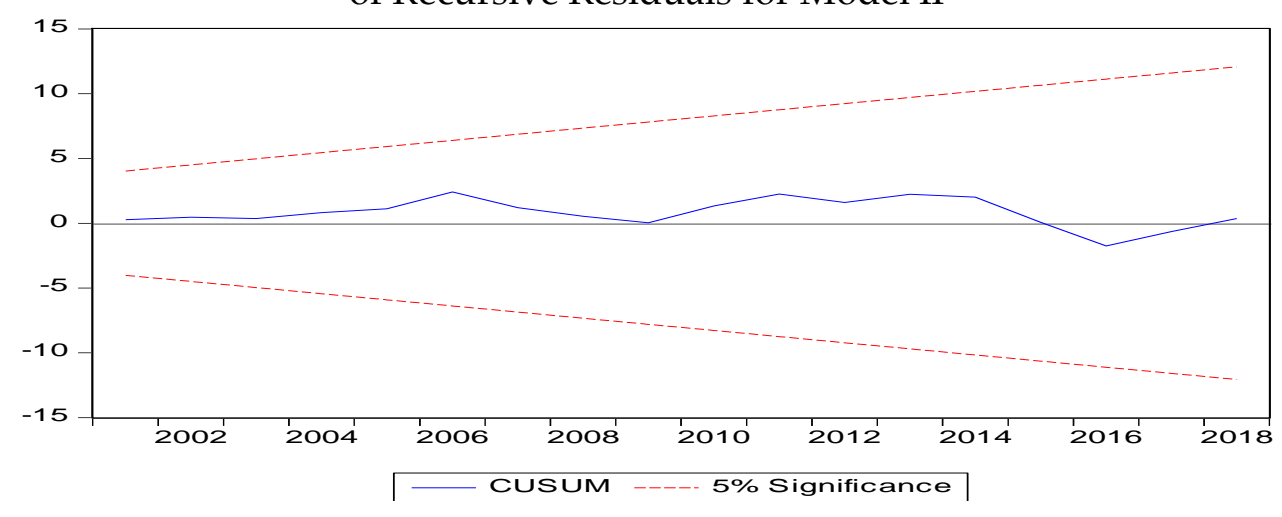

Figure 4.5b: Plot of Cumulative Sum of Squares (CUSUMQ) of Recursive Residuals for Model II

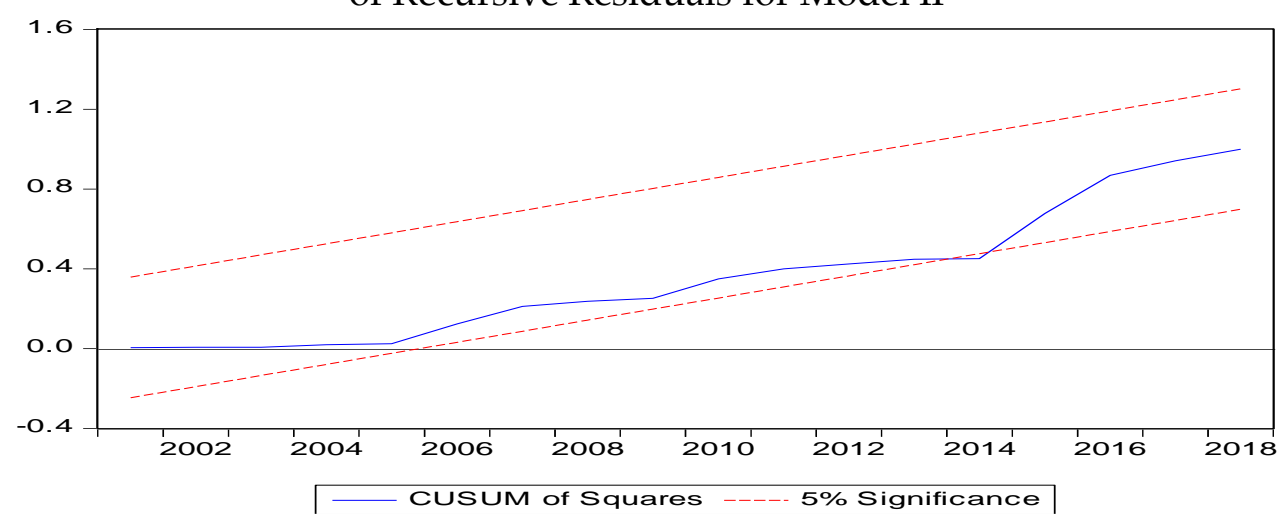


Figure 4.6a: Plot of Cumulative Sum (CUSUM) of Recursive Residuals for Model III

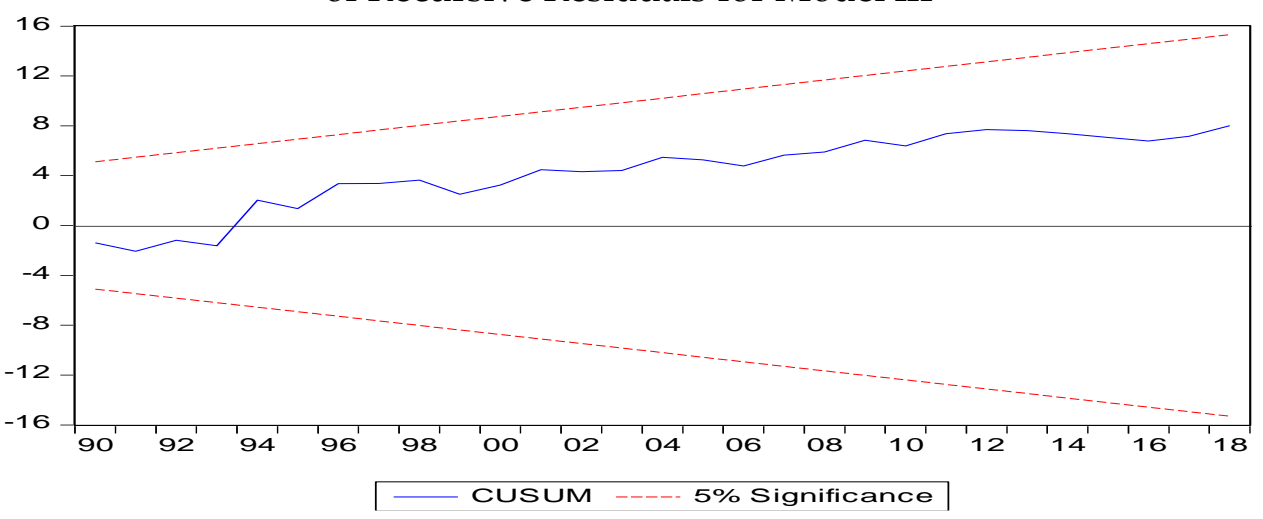

Figure 4.6b: Plot of Cumulative Sum of Squares (CUSUMQ) of Recursive Residuals for Model III

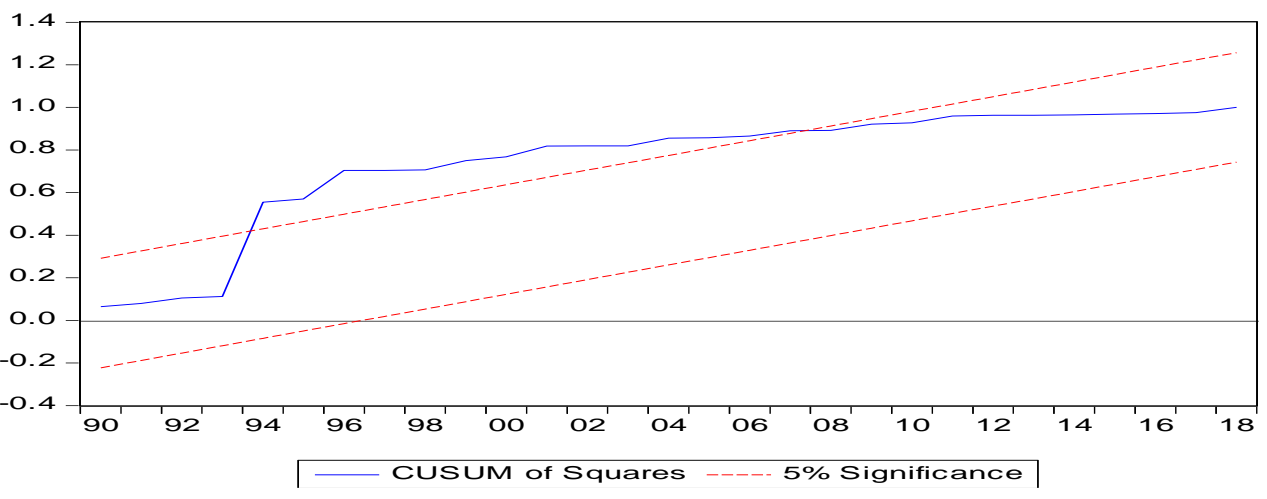

The stability test results are shown in Figure $4.4 \mathrm{a}, 4.4 \mathrm{~b}, 4.5 \mathrm{a}, 4.5 \mathrm{~b}, 4.6 \mathrm{a}$ and $4.6 \mathrm{~b}$ respectively in the models. The CUSUM and CUSUM of squares are the tests used to check stability within the model. Interestingly, it can be observed that both the CUSUM and CUSUMSQ statistics are rightly positioned within the critical bounds of $5 \%$ significance level. In other word, both the tests do not touch either of the red lines as probed on the graph. This implies that the model is stable which confirm good performance of the models and the inferences are valid, hence the required and essential condition.

\section{Conclusion and Recommendations}

Given the controversy that originates from Ricardian and Keynesian on budget deficit, there has not been a clear cut understanding on the macroeconomic effect of budget deficit in Nigeria. To this effect, this study probed the macroeconomic effects of budget deficit in Nigeria by adopting the ADF unit root test and ARDL model using annual time series data covering from 1981 to 2019 using simple Keynesian model, which was modified to incorporate our variable of interest. From our findings, it is evidence that budget deficit is significant and positively impact on economic growth in Nigeria. This finding shows that budget deficit in its sense is not a bad policy option for output expansion supporting the assertion of Keynesian and as well contradicting the belief of 
Ricardian that it crowd-out investment. However, further investigation reveals that budget deficit has negative and insignificant impact on private investment in Nigeria. By implication, the higher the budget deficit overtime, the lower the rate at which private individuals will embark on investment ventures. Also, it was discovered that budget deficit has positive and significant impact on public investment in Nigeria. Therefore, as government deficit financing increases, there will be a corresponding increase in public investment in Nigeria. Hence, we conclude that budget deficit promotes economic growth in Nigeria and encourage government to be thorough in the implementation of deficit financing because, it's a two edgesurd that can either better or worse any economic situation especially when the timing is wrong. Government must ensure and maintain strong fiscal discipline without compromising the wellbeing of the citizenry by allocating budget spending to sectors that can translate the deficit into high economic growth both in the short and long runs. Again, Government should channel deficit financing into investment in productive activities such as provision of capital goods such as roads, electricity, invention or provision of new technology, the economy might grow faster than the anticipated burden of the deficit financing in Nigeria. This will promote private individuals to embark on investment ventures.

\section{Conflict of Interest Statement}

The authors declare no conflicts of interests.

\section{About the Author}

Akamobi Obiageli Gloria is a lecturer in the Department of Economics, Faculty of Social Sciences, Faculty of Social Sciences, Chukwuemeka Oduemegwu Ojukwu University (COOU) (formally Anambra State University), Anambra State, Nigeria. She hails from Ihiala in Anambra State, Nigeria. She obtained her B.Sc in Anambra State University in 2006, M.Sc in Imo State University in 2016, and currently doing her Ph.D Michael Okpara University of Agriculture Umudike, Abia State with specialization in Quantitative Economics.

Unachukwu Ijeoma Blessing is a Department of Economics Education, School of Languages, College of Education (Technical), Umunze, Anambra State, Nigeria. She obtained her OND in Accountancy in Federal Polytechnic Oko in 2006, B.Sc Economics in Anambra State University in 2011, PGD Education in National Teachers Institute (NTI) in 2015, M.Sc Economics in Imo State University in the 2016 and Teachers Registration Council of Nigeria 2019.

\section{References}

Ahmed, M. \& Alamdar, A. (2018). Effects of corruption and budget deficit on private investment: Evidences from Pakistan. International Journal of Development and Sustainability, 7(6),1898-1913. 
Alesina, A., Favero, C. A. \& Giavazzi, F. (2018). Climb out of debt. Finance and Development. March, pp. 6 - 11.

Anyanwu, J. C. \& Oaikhenan, H. E. (1995). Modern macroeconomics Theory and Application in Nigeria. Journal Educational Publisher Onitsha.

Bedard, M. (2016). The Federal Government's deficits will not stimulate the Canadian Economy. MEI Viewpoint, Taxation Series. March, pp. 1 - 2.

Calderon, C. \& Fuentes, J. R. (2013). Government debt and economic growth. InterAmerican Development Bank (IDB) Working Paper Series, 424, 1 - 42.

Checherita, C. \& Rother, P. (2010). The impact of high and growing government debt on economic growth: An empirical investigation for the Euro Area. The European Central Bank (ECB) Working Paper Series. No 1237, 1 - 40.

Drazen A. (1979). Towards a political-economic theory of domestic debt. In: Calvo G., King M. (eds) The debt burden and its consequences for monetary policy. International Economic Association Series. Palgrave Macmillan, London.

Epaphra, M. (2017). Analysis of budget deficits and macroeconomic fundamentals: A VAR-VECM approach. Journal of Economics and Management, 30(4):20 - 57.

Ezeabasili, V.N., Mojekwu, J.N. \& Herbert, E.W. (2012). An empirical analysis of fiscal deficits and inflation in Nigeria. CS Canada International Business and Management, $4(1), 105-120$.

Ezeanyeji, Imoagwu \& Ejefobihi (2019). Public Debt and inflation in Nigeria: An econometric analysis. International Journal of Applied Research, 5(3), 219-224

Friedman, B. M. (1978). Crowding-out or crowding-in? The economic consequences of financing government deficits. National Bureau of Economic Research (NBER) Working Paper Series, 284, 1 - 51.

Hall, R. E. (1978). Stochastic implications of the life cycle-permanent income hypothesis: Theory and evidence. Journal of Political Economy, 86,971-987

IMF (2015). Fiscal policy and long-term growth. International Monetary Fund (IMF) Policy Paper. April, pp. 1 - 255.

Irons, J. \& Bivens, J. (2010). Government debt and economic growth. Economic Policy Institute (EPI) Briefing Paper, 271, 1 - 9.

Kindleberger, C. P. (1965). Economic development, $2^{\text {nd }}$ Edition. New York: McGraw-Hill.

MTEF and FSP (2010). 2012 - 2015 Medium Term Expenditure Framework and Fiscal Strategy Paper, pp. 6-13.

Nimani, A. (2013). Consequences of fiscal deficit. Journal of Economics and International Finance, 5(3):58 - 64.

Noveski, M. (2018). Macroeconomic effects of the budget deficit in the Republic of Macedonia. Croatian Review of Economic, Business and Social Statistics, 4(2), 5 - 14.

Nwanna, I. O. \& Umeh, G. N. (2019). Deficit financing and economic growth: The Nigerian experience. International Journal of Economics and Financial Management, $4(1), 28-49$.

Obadan, M. I. (2003). National development planning and budgeting in Nigeria, some pertinent issues. Broadway Press Ltd, Lagos.

Ogboru, I. (2006). Macroeconomics. Kaduna Liberty Publications limited. 
Oladipo, S. O. \& Ajisafe, R. A. (2015). Dynamic interactions among budget deficit, economic growth and poverty level towards capacity building strategy for sustainable development and poverty alleviation in Nigeria (1980-2012). Journal of Emerging Trends in Economics and Management Sciences, 6(7),169 - 174.

Ouattara, B. (2004). Modelling the long run determinants of private investment in Senegal. The School of Economics Discussion Paper Series 0413, Economics, the University of Manchester.

Paiko, I. I. (2012). Deficit financing and its implication on private consumption investment: The Nigerian experience. Arabian Journal of Business and Management Review, 1(10):45 - 62.

Pesaran, M. H., Shin, Y. \& Smith, R. J. (2001). Bounds Testing Approaches to the analysis of level relationship. Journal of Applied Econometrics, 16(3): 289-326

Schumpeter, J. A. (1934). The theory of economic development. Cambridge, MA: Harvard University Press.

Shahbaz, M. \& Rahman, M. M. (2012). The dynamic of financial development, imports, foreign direct investment and economic growth: Cointegration and causality analysis in Pakistan. Global Business Review, 13(2), 201-219. 
Creative Commons licensing terms

Authors will retain copyright to their published articles agreeing that a Creative Commons Attribution 4.0 International License (CC BY 4.0 ) terms will be applied to their work. Under the terms of this license, no permission is required from the author(s) or publisher for members of the community to copy, distribute, transmit or adapt the article content, providing a proper, prominent and unambiguous attribution to the authors in a manner that makes clear that the materials are being reused under permission of a Creative Commons License. Views, opinions and conclusions expressed in this research article are views, opinions and conclusions of the author(s).Open Access Publishing Group and European Journal of Economic and Financial Research shall not be responsible or answerable for any loss, damage or liability caused in relation to/arising out of conflict of interests, copyright violations and inappropriate or inaccurate use of any kind content related or integrated on the research work. All the published works are meeting the Open Access Publishing requirements and can be freely accessed, shared, modified, distributed and used in educational, commercial and non-commercial purposes under a Creative Commons Attribution 4.0 International License (CC BY 4.0). 